\title{
Humanization of Education in the Context of Janusz Korczak Pedagogical Ideas
}

\author{
Roza A. Valeeva ${ }^{1} \&$ Irina D. Demakova ${ }^{2}$ \\ ${ }^{1}$ Kazan (Volga region) Federal University, Kazan, Russia \\ ${ }^{2}$ Academy of Advanced Training and Retraining of Educators, Moscow, Russia \\ Correspondence: Roza A. Valeeva, Kazan (Volga region) Federal University, Kazan, Russia. E-mail: \\ valeykin@yandex.ru
}

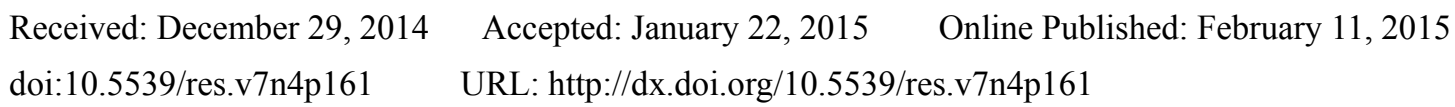

\begin{abstract}
The article investigates the problems of humanization of education. It updates the main objectives and results of this process: direction of the process of children's training and education in the development of the individual as an active subject of his perfection; change of the relationship in the dyad "adult-child", in which each respects the dignity of the person and another takes his goals, needs and interests. As the education paradigm shift factor in modern Russia a positive educational experience is named. The article reveals the pedagogical concept and practice of a prominent Polish humanist educator Janusz Korczak. His ideas became the basis for the establishment in 1993 of Korczak integration camp "Nash Dom" ("Our House"). Educational work in the camp is built on the ideas of J. Korczak intrinsic value of childhood, child rights, the dialogue between adults and children as their dominant relationship of forgiveness as a basic principle of academic work, the attitude to the child not as an abstract figure, but as a particular person and his real life. The authors describe a 23 -year-old experimental work of this camp, forms and methods of humanization of childhood space.
\end{abstract}

Keywords: Janusz Korczak, holistic system of education, childhood, the right to be respected for, self-organization, integration camp "Nash Dom"

\section{Introduction}

\subsection{Actualization of the Problem}

Eradication of authoritarianism in any form of education was a core idea of the pedagogical theory of the 20th century. It still remains the most topical issue of pedagogy. Achievement of this goal is closely linked with the personality of an educator, his/her skills, and will power. Ability of the educator to build good relations with his/her students is even more important than adopted methods of teaching, or perfect school buildings or state-of-the art facilities. In the global educational space there is currently a change of ideas about the nature and purpose of education. This causes the need to find new approaches to the organization of educational process, determining how to enable self-development and self-realization of children. The democratization of national systems leads to a paradigm shift of education, in which the person becomes more active subject of reforms in education. However it's necessary to consider that in the last quarter of the twentieth century, the world has undergone profound changes resulting from globalization. In this process, integration becomes the cornerstone of all changes in education. This leads to introduction of national education systems in a continuous process of reform with its main objective to improve the quality of education in the process of dialogue between different national education systems. Modern society is increasingly imperative in education of active, creative, internally free man who is aware of his worth and uniqueness and able to live in freedom, based on universal values, the relationship with the world and the achievements of civilization.

\subsection{Explore Importance of the Problem}

In this regard, relevant to modern Russian education is international experience, having constructive ideas of the humanistic oriented pedagogy. In the light of these provisions it's quite justified to appeal to the specific humanistic educational systems, developed and implemented throughout the twentieth century and have proved their efficiency in the process of interaction with various national educational systems. For Russian pedagogy - its history and present — one of the most significant was the theoretical understanding and practice of the prominent Polish educator 
and writer Janusz Korczak (1878 - 1942). He was the director of the orphanage in Warsaw, which provided security for every child, which was a unique phenomenon in pedagogic life of the XX $\mathrm{X}^{\text {th }}$ century Europe. In 1942 the Nazis doomed educators and 200 children from the Jewish orphanage managed by Korczak to death in a gas chamber of the camp Treblinka. Janusz Korczak shared the horrible fate of his children though he was repeatedly given a chance to save his life (Valeeva, 2003).

Janusz Korczak's orphanage was a new type of an orphanage, where organization of children's life was filled with deep humanism, with care about the child's welfare, and where everything was done to create conditions for the child's development and upbringing and to provide every child with security guarantees. Unlike many other children's orphanages, the goal set of this system presupposed the upbringing of an active and independent personality with developed humanistic qualities, and was based on the principle of the child's personality and rights respect as well as respect for the whole children's community, and on the principle of cooperation between "reasonable upbringing" and self-education activity of children. Educational, tutorial and organizational tasks of these orphanages made up a carefully designed system and included: correct moral and physical development of a child; organization of children's self-government for the benefit of upbringing and self-education; organization of life in the orphanage according to laws of equality; organization of educational influence of children's public opinion for the stimulation of children's self-educational activity; introduction of publicity into the orphanage's life; and connection of the orphanage with the environment, with particular attention to interaction with family. All this demonstrates effectiveness and vitality of Korczak's holistic system (Valeeva, 2010).

Janusz Korczak societies all over the world (Poland, Russia, Germany, Netherlands, Israel, Japan, Brazil, etc.) implement his ideas in the national education organizations. Teachers-enthusiasts, organizers of Korczak Kyouth movement in Russia try to create humanistic childhood area in their work. These associations exist throughout the country: in Moscow, St. Petersburg, Kursk, Perm and Kazan. The idea of serving a child, fighting for his rights, helping disadvantaged children became the main one in the activity of Korczak organizations both in Russia. For example, public organization "Pedagogical Fund "Humanist "was organized by teachers and students of Kursk State University, and its initial task is the work with children ill with leukemia. In such a way students gain unique human experience that will never let them show mental hardness and intolerance in future. Kazan youth Korczak organization "The sun for children" joins about 40 students, graduators, teachers and other people, who want to give love and care to children (Valeeva \& Rybakova, 2014).

Moscow youth - members of Korczak society organize since 1993 the annual international integration camp "Nash Dom" ("Our House") for children from families and orphaned children, healthy children and disabled ones (blind, visually impaired, etc.).The concept of the camp is the idea of Korczak about the rights of children, about the dialogue between adults and youth as the dominant relationship, about the benefits of forgiveness from educators (Demakova, 2013). This 20-year old experience helped to receive useful outcomes necessary in humanizing childhood area.

\subsection{Status of a Problem}

The problem of humanization of education is widely covered in the modern pedagogical studies in Russia. The subjects of works cover historical and pedagogical aspects of the principle of humanism (Nigmatov, 2004), the theoretical foundations of the teacher education humanization (Shiyanov, 1991) humanization of childhood space (Demakova, 2000). The main trends in the development of humanistic ideas in the theory and practice of foreign schools and pedagogy are revealed by Bim-Bad (1994), Dzhurinskiy (1993), Kornetov (1993), Tsyrlina (1999). Feldstein (1994) examines the possibilities and conditions of social and personal development of the child. Many aspects of the humanization of education investigated Novikova (1985) and Selivanova (1989). Psychological bases of the humanization of pedagogical activity investigated Asmolov (1990), Bodalev (1995), Bratchenko (1999), Zimnyaya (1997), Slobodchikov and Isaev (1995). Development of alternative education as a phenomenon of the humanization of education is revealed in the works of Valeeva and Vafina (2014), Valeev and Valeeva (2014). Educational system of Janusz Korczak is researched in the works of Valeeva (2003).

\subsection{Janusz Korczak's Pedagogical Ideas}

Educational ideas of Janusz Korczak were developed in a dramatic struggle with the social environment. An early understanding of social injustice towards children contributed to the formation of his original concept, according to which any society was split into two big groups or classes - one of adults and the other, the oppressed one, of children. Searching for the reason of the children's oppressed status in the society, Korczak came to understanding the opposition of two worlds - the world of adults and the world of children. On the one hand, Korczak has become an advocate of children's interests and rights against tyranny and lawless behavior of 
adults and, on the other hand, he was trying to find ways for them to be reconciled and reach mutual understanding.

No less important is the Korczak's view of children as a social stratum is his assurance of the absolute value of childhood. Korczak's holistic system of education generally rests upon it. "Childhood", he wrote, "is a long important period in a person's life" (Korczak, 1979, p. 15). "...Childhood is mountains where the river originates and where its direction is determined" (Korczak, 1978). He repeatedly emphasized the significance of a happy, joyful childhood in the formation of personality and believed that without a complete childhood the whole life of a person would be maimed. Therefore, Korczak strove to increase the teachers' responsibility for the child's "present day": "This present day should be clear, full of cheerful efforts, absolutely childish, careless with no responsibilities which do not correspond to the child's age and powers. I ought to provide for him an opportunity to use up his energy, I ought-regardless of the insulted written law's rumble and its ferocious clauses - to give the child all the sun, all the air, all the benevolence that he deserves regardless of his merits or faults, his virtues or vices" (Korczak, 1979, p. 41).

Korczak believes that children possess a multitude of rights, which adults must implicitly admit. The child has the right for respect of his ignorance and his cognitive labor; his failures and tears; mysteries and deviations of the hard labor of growth; the current hour and the present day; the mystery of correction; efforts and credulity. No less important is to admit the child's right to be what he is. Adults must also admit the child's right to: participate in discussions and judgments which concern him directly; experience considerate attitude towards his problems; express his ideas; organize his life independently; use his virtues and conceal his faults; protest; to make mistakes; have a mystery; move; property; play; and, finally, the right to die.

The principle of respect for the child's personality and rights did not just reflect the humanistic positions of the Polish educator and touch upon the problems of an abstract teacher's relations with imaginary children. The humanism of Korczak's pedagogy was distinguished, first of all, by its effectiveness-Korczak's pedagogical principles were implemented in the reasonable educational process organization of Dom Sierot (The Orphanage) and Nasz Dom (Our House) - the child-care facilities founded by him. All these principles became the base of the activities of "Nash Dom" Korczak summer camp.

\subsection{Janusz Korczak’s Holistic Educational System}

The important feature of Korczak's orphanages was adjustment of entire life organization to the child's physical and mental development needs. They held the whole set of activities, intended to contribute to healthcare and correct development (rational nutrition, personal hygiene and home hygiene, opportunity to have necessary rest and sleep, open air exercise, constant measure of height, weighing, and other systematic research).

The goals and objectives of Korczak's childcare institutions also differed significantly from the aims of traditional upbringing. In the article, "Ku Otwarciu Domu Sierot" ("On the Opening of The Orphanage"), Korczak formulated the primary tasks in the following way:

1) To study the child and the laws which regulate his development, for the most part, mental and physical; to pay special attention to physical upbringing;

2) To create "the house of labor and the school of life" on the basis of the orphanage, to impart labor skills to children, to help them in the choice of profession according to their abilities;

3) To study and find out the reasons of unbearable atmosphere in the boarding schools in order to find ways of improving them (Korczak, 1913, pp. 2-4).

Later he described the holistic program of the orphanage, the central idea of which was "good will, and service of the child", in a more detailed manner (XXY lat..., 1933, p. 48). In the article "A Jewish Child" he highlights the most acute problems of the boarding school: "how to coordinate the needs and goals of the administration and children, the responsibilities and individual will, the reasonable desires and whims; how to protect the subtle and sensitive nature of children; how to hamper the quantitative growth of those who represent a problem and disparage the status of a human by their sole existence" (Korczak, 1933, p. 243).

He believes, that thereto it is necessary to establish a children's community based on equity, fraternity, equal rights and responsibilities. In the course of holistic system formation Korczak was mostly concerned with the problem of the way a child feels himself in the group of other children, and with the associated problem of how to establish correct relationship between teachers and children.

To implement this complicated holistic program the teachers were to:

- Organize the children's labor, 
- Find the form of children's conflict settlement,

- Establish a bright and happy way of life,

- Organize the self-government,

- Influence children through the opinion of the milieu,

- Motivate children to strive for self-education,

- Combine the principle of publicity with the principle of respect towards the child's inner world,

- Do all their best for the gradual transition from control and assessment of children's groups to their self-control,

- Use educational methods and means which were to be simple and clear for the children,

- Act carefully and slowly, being sensitive to cooperation with children (Rogowska-Falska, 1959, p. 17).

The main idea of Korczak's educational concept is connected with the problem of child's feelings, especially in the environment of a large children's community. It was the concern for the child's well-being that dictated children's self-government organization of life. The necessity to resort to the children's self-government as the leading way of children's life organization was also dictated by the aim that Korczak and his collaborators set for themselves - the upbringing of an active and independent personality. Creating this original kids' society, he began with what in any society is a criterion of an effective democracy-with establishment of a court. Korczak organized a community court with the primary goal of protecting every child. Moreover, he wanted the child's fate to be independent from good or bad will, from good or bad mood of a teacher. In the basis of the community court, there lies the principle of respect for the children and earnest attitude towards their problems. The court also became a regulating body concerned with teachers and inmates' relations, the framework of mutual respect and cooperation.

The court made decisions according to the Code, which was designed by Korczak himself. The Code taught the children to be fair, considerate towards their fellows' mischief, it educated both judges and those, whose cases were examined in court. The contents of the Code were in a logical line with Korczak's declared principle of the child's personality and rights respect and with trust towards children, and were primarily aimed at correction of a child, not his punishment; it supported faith into the possibility of such correction.

The superior body of children's self-government in Korczak's orphanages was represented by seim. It was elected once a year and included about 20 deputies chosen by way of general plebiscite. Seim was responsible for accepting or declining the resolutions of the Self-Government Council, for establishing holidays and memorable dates in the orphanage, and for assigning awards. Later the prerogatives of Seim broadened to such an extent, that it took part in making decisions concerning admission and expulsion of pupils.

Along with the Self-Government Council, there was the Staff Council, which consisted of expert teachers and was responsible for goals realization, for upbringing direction and the results of the educational work, for the tutorial work, for the organization of children's life, and for every child's physical and mental development.

In the given system of the children's and adults' communities' cooperation, a lot of attention was paid to general meetings of an orphanage. The general meetings taught children to solve the issues of their lives in a team. In addition, those general meetings promoted public opinion, which was the primary way of making an impact upon an individual child. The meetings contributed a lot to the publicity principle reinforcement inside an orphanage, which ensured neutralization of some negative phenomena in the relationships inside the community.

Labor in Korczak's orphanages was a significant factor of upbringing. Not only Korczak did his best to inculcate respect for people of labor and evoke recognition of necessity of any labor — be it mental or physical—in his wards, but he also wanted to cultivate certain practical skills, independence and conscientiousness, an ability to get on well with fellow pupils in the process of labor in them, he wanted to teach them to control themselves and others, to develop will and initiative of children, i.e. develop those qualities that are very important for a grown-up person.

Duties, which in Korczak's holistic system were not a mere alternation of some responsibilities fulfillment, facilitated realization of these important objectives of labor education. This term was defined as children's fulfillment of certain voluntary responsibilities during a long term (no less than a month or more). All the housework was divided into duties, which accounted for twice as more as there were children because some of the duties were carried out by several children. Thus, in the orphanage every pupil had a certain responsibility, which changed every month. It is necessary to mention that duty enrollment was voluntary and work was considered a public duty. At the end of each month, children applied for the next month's duties. The 
Self-Government Council assigned all the house responsibilities according to those applications.

The most vivid and distinctive feature of Korczak's holistic system was the organization of the public opinion in the children's community. The weekly newspaper of the Orphanage helped greatly to express public opinion in the children's community. These weekly newspapers raised a number of questions. The most urgent topics concerned difficulties of labor, e.g. economic problems or unwanted phenomena in the children's social life. The newspaper was a kind of a mirror reflecting life in the children's institution, "a precious scientific document": it informed, directed attention to drawbacks, covered all the questions concerning children's life.

The so-called plebiscites of benevolence and malevolence exhibited the children's common opinion in the clearest way. Plebiscites were organized after the following: 1) one month of a newcomer's life in the Orphanage (including teachers); 2) one-year stay, before receiving a civil status; and 3) upon discussing the question of pupil's correction or rehabilitation. The plebiscite, or the general secret ballot of children, had the following procedure. The pupil who was to undergo the plebiscite was announced beforehand, a day before the plebiscite; next day at breakfast, they put cards with "pluses" (I like, I respect him/her), "minuses" (I have negative attitude towards him/her), and "zeros" (I am indifferent towards him/her) before every child. Children had time to think and decide which card to choose; therefore, the ballot went fast and smoothly. The language of numbers defined the child's or teacher's place in the community in a simple and absolutely precise way.

Plebiscites formed such important qualities as courage, adherence to principles, and honesty in pupils. Moreover, with the help of those plebiscites, teachers could explore children's relations, conditions of their emergence and development.

We need to point out that plebiscites urged children to develop on their own, while civil statuses given to children annually helped to determine the limits of self-perfection. After a one-year stay in the Orphanage, a pupil, who had been considered just a "newcomer", received a civil status. Civil statuses were conferred by the Self-Government Council according to the results of the plebiscite, the number of lawsuits and labor units earned by a child, and academic progress. Upon these data discussion, he was awarded one of the following statuses: fellow, tenant, indifferent tenant, burdensome alien. Each of these statuses gave certain rights and privileges as well as legal restrictions.

While the plebiscite and civil categories helped a child in self-actualization and self-evaluation, i.e. acted as the first stage of the self-education process, the skills of self-possession, self-control and self-criticism were formed with the help of a well-designed system of the self-education stimuli, which directed a child and helped him in the desired goal achievement. Moreover, this system was based on the actual evaluation of individual abilities. Worth mentioning are the individual bets - voluntary pledges of children referring to themselves made in the presence of a teacher, who acted as the child's secretary and counselor.

Korczak accepted the bets once a week, always on the same day, early in the morning before breakfast. On the pages of a thick impressive book, in the first column, he would put down the matter of the child's bet and the quantity of violations, and in the second column, he wrote if the child had won or lost, and the score. There was a variety of matters: fights, molestations, abuses, neglected studies, theft, etc. Sometimes, especially in the awkward age, a child could make a bet concerning intimate questions known solely to him. In this case, they would generally put down Xs because pupils were allowed to bet on something "unrevealed".

A wise psychologist and an expert educator, Korczak knew that no bet could correct a child right away. Some time full of inner struggle had to pass from the betting moment to the generation of a certain skill. A lost bet would provoke chagrin while victories would arouse joy and satisfaction. In this case, a normal feeling of childish pride starts working, and it helps a child to overcome his flaw.

The aim, the basic principles and humanistic orientation of Korczak's holistic system determined the choice of the primary educational method - the method of children's self-government. Active children's self-government in Korczak's system was the form of organizing adults and children cooperation that contributed to creation of an integrated educational community. Self-government was also the most reliable means of adults and children relations humanization, which helped to build those relations on the ground of cooperation and mutual understanding. That style of relationship produced an actual moral result: children felt they were equal with teachers and realized that they were equally reliable with adults for the life of the orphanage. Yet, dignity is a necessary item for the child's security in the system of relations.

This very moral atmosphere of the orphanage, which provided security for every child, demonstrates that Korczak's holistic system was a unique phenomenon in pedagogic life of the $\mathrm{XX}^{\text {th }}$ century Europe. This is a new type of an orphanage, where organization of children's life was filled with deep humanism, with care about the 
child's welfare, and where everything was done to create conditions for the child's development and upbringing and to provide every child with security guarantees (Valeeva, 2010).

\subsection{Hypothesis of the Study}

Analysis of theoretical and practical teaching and research activities in the aspect of the developed problem showed that it is the understudied area of scientific knowledge and practical activities. This enabled to formulate hypotheses of the study: the process of humanization of education would benefit if:

- It is formed on the knowledge of the main Janusz Korczak concepts of childhood self-value, children's rights, reasonable up-bringing;

- To take into account the ideas of integration children in the camp as a model of holistic world;

- To develop and test a program of Integrative Camp "Nash Dom” realizing Korczak's humanistic ideas.

\section{Materials and Methods}

\subsection{The Tasks of the Research}

The study addressed the following objectives: 1) To analyze the psychological and pedagogical literature for the study of "humanization of education" notion; 2) To select the main factors of humanization of education; 3) To describe Janusz Korczak pedagogical ideas as means of humanization of education; 4) To develop and test a program of Integrative Camp "Nash Dom” realizing Korczak's humanistic ideas.

\subsection{Theoretical and Empirical Methods}

We used methods of theoretical studies (systematization, classification, comparative analysis), which allowed to determine the approaches to the process of humanization of education; analysis and generalization of mass and excellence organization of children's communities; theoretical modeling with subsequent verification in experimental work of teacher education; scientific expedition as a specific method of complex research, which can provide an array of information; sociological methods (surveys of children participating in the experiment, interviews, content analysis of children's artwork, video and photo registration process communication in the "teacher-child"); pedagogical methods of forecasting, including the examination; experimental work.

\subsection{Base of the Study}

Pedagogical experiment was held in Korczak Integrative Camp "Nasz Dom" since 1993. 23 Summer and 22 Winter camps were organized since that time. Each camp is interesting and not like one another, but all of them, from the first in Taganrog in 1993, until recently also in Kazan (2014), have in common - they are based on the conceptual ideas of J. Korczak. The unique project of Korczak camp from the very beginning was conceived as a joint organization of children with disabilities and healthy children from different kinds of home: large, complete and incomplete, successful and disadvantaged families, children from low-income segment of the population and of the families very wealthy (so called "new Russians"), children with problems in learning and communication, social outcasts, not adopted by school teachers, and advanced pupils; children of three races, more than twenty nationalities from different countries at the age of 6 to 17 years. Thus one of the essential characteristics of the camp is its integrative nature.

\subsection{Running and Description of the Experiment}

Community integration is a specific medium. Every child, coming to "Nasz Dom", falls into a rather complex organization, interconnection and integration relations community. It is obvious that this community does not arise spontaneously, it is the result of adult team purposeful educational activities, united ideologically, possessing the technology collaboration children from different social groups and with different levels of physical health, capable of constant creative search. Getting in the integrated community, which was established before the arrival to the camp, each new child quickly becomes part of it, and it is for him to become a full time living together the center of his life, behavior, thoughts and feelings.

Integration of children is realized in a variety of joint activities, physical rehabilitation of children by involving them in feasible sports activities, the development of legal culture, constructing of relationships in the camp like in a democratic society.

In the first days a new child staying in the camp needs a specially organized activities "the guide-parents" to lift anxiety, maladjustment, to create a favorable psychological climate, attitudes and values in the whole camp and each family emerging children's collective. These tasks are in addition to specially selected communicative games, exercises, training assignments decide as traditional "Nash dom" events such as "Meet the brand-new." At these meetings, children and group leaders who come to the camp not for the first time talk to the new guys 
about the life of Janusz Korczak, his fate and pedagogical heritage, about the traditions and customs of the camp. At this meeting we learn the name of each child who came to the camp for the first time, and ask him about the expectations associated with the new change in the camp. These meetings help new children to feel cared for by children - the "oldies" and counselors, to feel involved in the long history of the unique camp and become a full member of the whole camp and friendly staff.

The children and adults have equal rights; self-government is organized on the model of Korczak's orphanage including children's parliament, newspapers, organization of labor. Like in Korczak's orphanages children use here mailboxes where they can drop the anonymous letters and notes; the bulletin board is used, plebiscites on the most important events are held. All this provides young leaders of the camp with feed-back which helps to make proper decisions.

Integration is understood by us as the common life of children from different social groups, which is ruled by humanistic ideas of Janusz Korczak on the Rights of the Child, on the dialogue between adults and children as their dominant relationship; on forgiveness as a basic principle in up-bringing. One of the leading Korczak's ideas, which is the basis of life in the camp is the child's right to be respected. By Korczak it is the most important right of any child. It is the result of a teacher's conviction that a child as an active and independent human being can himself organize his life. The idea of independence is the conceptual idea of Korczak who was convinced that only knowledge, obtained independently and experienced by a child, becomes a means of his development. So Korczak's idea of children's independence is a conceptual idea of the camp.

In the conception of the camp the developed by Korczak children's rights are reflected: the right for making mistakes, for privacy and respecting children's lack of knowledge and skills; the right for using their strengths and hiding their weaknesses, for activity and games. Many of the Korczak's conceptual ideas are reflected in the Constitution of the camp.

One of the most important areas of work with children is their intellectual and creative development. There are a lot of different circles and workshops in the camp. Children learn foreign languages, go in for singing, drawing, dancing, playing the guitar; they take part in festivals and competitions. Role playing and psychological trainings conducted by counselors or invited experts are very popular in the camp.

An important feature of the camp is its international character. The idea of organizing a camp as an international place appeared at the same time with the idea of its creation. This idea was actively discussed in the first Korczak camp in 1993 in Taganrog. The idea of setting up a camp as an international organization is manifested primarily in its "personnel policies". Nowadays young people from Russia, Ukraine, the Netherlands, Germany, USA, Switzerland, and Spain work in the camp. They are mainly active participants of Korczak movements in their countries: teachers and students of different universities, young teachers, social workers, psychologists, as well as translators, actors, musicians, and engineers with an interest in the problems of children and childhood. The camp life is subordinated to rules which are collectively developed during the existence of the camp.

One of the main tasks of our activity is training group leaders to work with children, formation of reflection, starting conditions of understanding and organization of communications. Our experience shows that the most important thing in this process is to respect the searching of every young man (even within a single team), of his direction, his style of communication with children, his pedagogical methods. The result of this creative process is gathering and publication of materials of group leaders' observations, reflecting the overall work (now in the archives of the camp more than 2,000 pages of different texts: a newspaper diary "Days of Our Lives" (50 issues), a newspaper "Parliamentary Bulletin", family newspapers, video scripts, poems written by blind and children who cannot see, drawings, photographs, etc.

The international nature of the camp is seen in the children's part of it. During 23 years in addition to Russian children the children from Ukraine, Netherlands, Germany, Estonia, Italy and Canada spent their holidays here.

The main purpose of the camp counselors is creation and preservation of the special atmosphere in the camp. This atmosphere has its own special joyful bright colors and "temperature"-constant warmth and warm-heartedness which help to full trust, a lot of positive emotions, deep feelings of friendship and love. Creating of such an atmosphere is a very complex psychological and pedagogical problem. Its emergence and development is the result of very significant efforts: discussions, dialogues, debates, cooperation of children and adults. Our experience shows that children willingly involve in the creation of such an atmosphere, they appreciate it and try to keep it. And this is a general sense to which we have given the name-the emotional memory.

There are some traditional techniques used in the camp. 
"Sbor" - the traditional meeting of the camp in a large circle, where all together, arm in arm, we sing their favorite songs, and then headleaders come to the center of the circle asking children about the day, and talk about the plans for tomorrow. Everybody can say "thank you" to each other, passing around the ball. "Sbor" is the most important event of the day in the camp, everybody carefully prepares, wearing a green tie, and making sure not to miss the beginning.

Camp candle - the most romantic and emotional event. On the camp candle we lit traditional camp houses around which spread out mats where children sing favorite songs, embracing, thinking about beauty. Everybody can talk and sing their songs. Usually the camp candle lasts until late at night.

Family candle - a traditional meeting of the family, when children gather in a small circle to discuss issues connected with relationships in the family, playing games, preparing for the event, walking with the family and camp parents. Children love the family candles, because they create a special "family atmosphere", which is not enough for many children in their life.

"Korczak Day". Korczak day we start with a silent march: early morning children and group leaders, lined up in pairs, holding candles in absolute silence, go to the sea or river, where they float candles and sing songs, read poetry and prose about Korczak. This morning represents to the children the Korczak final way to the camp Treblinka.

Camp Birthday - one of the favorite holidays for all children. All night the group leaders are preparing for this holiday, inflating balloons, hanging garlands, preparing cards and gifts for their children. The whole day kids congratulating each other and, of course, everybody receives gifts from one another and from the camp. At night, the children put a shoe under the door and in the morning find there a soft toy. At the evening we blow out the candles on a huge cake and show a concert.

Self-government day - this day is a very important day for senior families and one of the most exciting days for the younger children. The whole night and the next day all the kids conduct without group leaders, and the children themselves become group leaders. Seniors take patronage over the younger ones. Everything is as usual-mothers and fathers for each family, caretaker, doctor and some leaders. Children think through the plan of the day for themselves, spend all of their own regime moments and events. Succession of generations is developed very well in our camp. Group leaders and leaders are often those who had been a child in the camp beforehand. So for older children, Self-government day is a great opportunity to try their hands at the role of future leaders.

One activity is replaced by another, the dynamics of the event is very high, higher saturation affairs and concerns - it is a feature of life for all children's groups. All these technologies do not only form a favorable psychological climate in the camp as a whole, but also promote adaptation of the individual child.

The children repeatedly change their roles and behavior in society during of the change-from the leadership to a member participating in various activities, which ensures the development of his creative abilities through decisions, management team in drawing wall newspapers or training evening activities with a group leader in conducting games. Accumulation of roles allows to gain confidence and develop communication skills.

What is this activity in reality?

For adults it includes efforts to study children, their inclusion in a variety of activities, involvement in the creation, adoption to pedagogical support of each child by children and adults.

For children it is a constant display of activity, independence, initiative and support of proposals which children and counselors advance, constant readiness not only to participate in all, but to become an initiator of any undertaking in the camp.

Thus teaching staff draws in the creative legacy of Janusz Korczak the following important pedagogical values: respect for the personality of a child; the choice of dialogue as a priority in a way of interaction between adults and children; the principle of forgiveness which is reflected in the idea of trust to the child; the faith in his power; optimistic assumption about his success in the life of the camp, etc. So the camp uses Korchak's experience, including the experience of self-government. It is here where humanistically oriented system of educational activities and educational approaches of bringing-up space in the camp originate.

\section{Results}

In 2012 the Korczak camp "Nash Dom" celebrated its 20th anniversary. Over the years about two thousand children spent their vacation in this camp; about 350 young people (students and graduate students from different countries) worked here as counselors. 
At the end of the shift camp the group leaders were asked to answer a series of questions. Analysis of these responses allows us to draw conclusions as to what issues excite counselors in the camp and beyond it, what makes them to be happy and sad; what they like and dislike.

The main findings can be summarized as follows:

For young leaders the most important question of their work in the camp was the meaning of their activity. Answering the question: "How do you understand the main idea of the camp "Nash Dom" they emphasized on the following:

- To make children happy, to show them that they are worthy of respect, so that the children from single-parent families can feel themselves as a part of the family and home with Mom and Dad;

- Unity, tolerance, ability to listening, communication;

- Friendship between healthy children and children with disabilities;

- To love kids, to talk to them as equals;

- The integration of children from different social groups with different abilities, from different countries and cities in a single community;

- Each child should be loved and able to love others and the world;

- It is necessary to create good conditions for the children to live;

- To find a soul in oneself and hold it; to see the soul in other people and in children;

- To keep the memory of J. Korczak and his ideas; to educate children in accordance with these ideas;

- To follow the idea of universal love to the child and community;

- Attention to the child, his life, hobbies and dreams.

And here are the common positions presented by children:

1) Priority ideas connected with the fate of J. Korczak; interest in his pedagogical legacy and commitment to its ideals.

2) The democratic nature of the community which was formed by young leaders from western countries where they have a rich experience in the organization of democratic discourse.

3) Discussion and joint development of solutions on the fundamental documents of the camp: the constitution, the structure of the camp, organization of self-government, different creative circles, meetings and others.

4) Inclusion into the life of the camp humanistic traditions, supported by the international Korczak organizations (i.e. serious attention to the rights of children, etc.) included in the way of camp humanistic traditions of other countries.

From the first day of the camp the problem of emotional balance among group leaders from different countries was in the center of our attention. Special questionnaires designed to clarify these issues, showed a stable atmosphere of the camp, which is always an indication of successful development of the community.

\section{Discussions}

At the same time the international nature of the camp life creates different problems, which under certain conditions can become an obstacle in the development of children's and adult communities. First, here is a question of language difficulties. The camp communication is conducted in Russian, English, Dutch and other languages. In connection with the integration in the children's community of blind children written communication (ads, etc.) are also available in Braille. The camp runs language circles, in particular the circle of Russian for counselors and trainees from other countries. For all the years circles of English, Dutch and German have been working for children who are taught songs in different languages, etc.

\section{Conclusion}

The process of personal growth of children in the camp has real positive effects because of the birth in them a sense of belonging to a community. It often it compensates for many children the lack of a family thus providing emotional stability of their existence; providing the opportunity to experience the joyful moments of self-acceptance by themselves as adults and children; creating a sense of security and psychological comfort. 
Our experience shows that the conditions of personal growth of children of different ages, social groups, races, nationalities, countries, health ensure to a large extent sincerity, openness and willingness to engaging a dialogue, acceptance, respect, empathy, care and understanding of their young colleagues and adults.

\section{Acknowledgment}

The work is performed according to the Russian Government Program of Competitive Growth of Kazan Federal University.

\section{References}

Asmolov, A. G. (1990). Personality Psychology. Moscow: MSU.

Bim-Bad, B. M. (1994). Pedagogical currents at the beginning of the twentieth century. Moscow: ROU.

Bodalev, A. A. (1995). Personality and communication. Moscow: MPA.

Bratchenko, S. L. (1999). Introduction to humanitarian expertise of education (psychological aspects). Moscow: Smysl.

Demakova, I. D. (2000). The educational activities of the teacher as a factor in the humanization of childhood space ( $\mathrm{PhD}$ dissertation). Moscow: Russian Academy of Education.

Demakova, I. D. (2013). Janusz Korczak: Alive pedagogy of the changing world. Moscow: ANO "CNPRO".

Dzhurinskiy, A. N. (1993). International School: Current status and development trends. Moscow: Prosvetsheniye.

Feldstein, D. I. (1994). Psychology of personality formation. Moscow: International pedagogical academy.

Korczak, J. (1913). Ku otwarciu Domu Sierot. Warsawa.

Korczak, J. (1933). Dziecko zydowskie (Opinia rzeczoznawczy). Miesiecznik Zydowski, 3, 239-243.

Korczak, J. (1978). Pisma wybrane. Warszawa: Nasza Ksiegarnia.

Korczak, J. (1979). Selected pedagogical works. Moscow: Pedagogy.

Kornetov, G. B. (1993). Humanistic education: Traditions and perspectives. Moscow: ITPIMIO.

Nigmatov, Z. G. (2004). Humanistic bases of Pedagogics. Moscow: Vysshaya shkola.

Novikova, L. I. (1985). School and the surrounding space. Moscow: Znaniye.

Rogowska-Falska, M. (1959). Zaklad wychowawczy "Nasz Dom”. Szkic informacyjny, Wspomnienia z malenkosci, Warszawa.

Selivanova, N. L. (1989). The educational system of the school. In Problems and quest. Moscow: Znaniye.

Shiyanov, E. N. (1991). Humanization of Teacher Education: Status and Prospects. Stavropol: SGPI.

Slobodchikov, V. I., \& Isaev, E. I. (1995). Human psychology. Moscow: School-Press.

Tsyrlina, T. V. (1999). The phenomenon of the author's humanistic school in pedagogical culture of the twentieth century. Kursk: KSPU.

Valeev, A. A., \& Valeeva, L. A. (2014). Free Education: Pro And Contra. Procedia - Social and Behavioral Sciences, 131, 66-69. http://dx.doi.org/10.1016/j.sbspro.2014.04.081

Valeeva, R. A. (2003). Pedagogical concept and educational practice of Janusz Korczak. Samara: Profi.

Valeeva, R. A. (2010). Janusz Korczak's Holistic System of Education. Russian-American Educational Forum: An Online Journal, 2(1), $1 . \quad$ Retrieved from $\mathrm{http}: / / \mathrm{www}$. rus-ameeduforum.com/content/en/?task=aut\&aut=2000055\&iid=6

Valeeva, R. A., \& Rybakova, L. A. (2014). The Role of Youth Organization in the Development of Higher Educational Institutions Students' Humanistic Value Orientations. Procedia-Social and Behavioral Sciences, 141, 817-821. http://dx.doi.org/10.1016/j.sbspro.2014.05.142

Valeeva, R. A., \& Vafina, D. I. (2014) Comparative study of American and Russian students' attitude towards alternative education. Life Science Journal, 11(12s), 821-824.

Zimnyaya, I. A. (1997). Educational psychology. Rostov-on-Don: Phoenix. 


\section{Copyrights}

Copyright for this article is retained by the author(s), with first publication rights granted to the journal. This is an open-access article distributed under the terms and conditions of the Creative Commons Attribution license (http://creativecommons.org/licenses/by/3.0/). 